\title{
ANALISIS TINGKAT PARTISIPASI PESERTA KELUARGA BERENCANA DI KAMPUNG KB KELURAHAN HANDIL BAKTI KECAMATAN PALARAN KOTA SAMARINDA
}

\author{
Endang Wiwiek.P ${ }^{1}$, Sri Utami ${ }^{2}$ \\ ${ }^{1,2}$ STIKES Dirgahayu Samarinda \\ Jalan Pasundan nomor 21 kelurahan jawa kecamatan Samarinda Ulu ,75122 \\ wpurnamawaty@yahoo.co.id
}

\begin{abstract}
ABSTRAK
Kampung $\mathrm{KB}$ adalah miniatur pelaksanaan program $\mathrm{KB}$ secara terpadu dan komprehensif ditingkat lini lapangan (desa/kelurahan/dusun/RW). Konsep kampung KB merupakan konsep terpadu program KB dengan program pembangunan lainnya seperti pendidikan, kesehatan, ekonomi dan lain-lain. Kampung KB didesain sebagai upaya pemberdayaan masyarakat terhadap pengelolaan program KB pada kelurahan Handil Bakti Kecamatan Palaran. Tujuan akhirnya tentu pembangunan masyarakat itu sendiri. Pemerintah hanya menstimulasi dan melakukan pendampingan, selebihnya menjadi tanggungjawab masyarakat. Pemerintah bertanggung jawab memberdayakan dan mendorong peran serta aktif keluarga atau masyarakat dalam segala bentuk meningkatkan kesejahteraan (Notoatmodjo, 2005). Desain yang digunakan adalah deskriptif analisis, dimana populasinya adalah ibu peserta keluarga berencana yaitu sejumlah 60 responden. Teknik pengambilan menggunakan total sampling. Pengumpulan data menggunakan instrumen penelitian yaitu angket berupa kuesioner. Dari analisa yang diperoleh dari 60 reponden $53(88.33 \%)$ dengan pengetahuan baik, sebanyak 38 responden $(63.33 \%)$ menggunakan alat kontrasepsi efektif. $p$ value pada uji statistic adalah $0.00<0.05$.
\end{abstract}

Kata kunci : partisipasi , sikap, keluarga berencana

\section{PENDAHULUAN}

Kampung KB merupakan salah satu "senjata pamungkas" baru pemerintah dalam mengatasi masalah kependudukan, terutama di wilayahwilayah yang jarang "terlihat" oleh pandangan pemerintah. Kampung KB, kedepannya akan menjadi ikon program kependudukan, KB dan Pembangunan Keluarga (KKBPK). Kehadiran Kampung KB bertujuan meningkatkan kualitas hidup masyarakat di tingkat kampung atau yang setara melalui program KKBPK serta pembangunan sektor lain dalam rangka mewujudkan keluarga kecil berkualitas.. Peningkatan ketahanan dan kesejahteraan keluarga dapat ditelusuri melalui berbagi indikator yang merupakan pencerminan dari pelaksanaan delapan fungsi keluarga. Hal tersebut tercantum dalam Peraturan Pemerintah No 87 Tahun 2014 tentang Perkembangan Kependudukan dan Pembangunan Keluarga, Keluarga Berencana dan Sistem Informasi Keluarga

Berdasarkan latar belakang di atas , maka penulis tertarik melakukan penelitian mengenai Partisipasi Peserta Keluarga Berencana di Kampung KB Kelurahan Handil Bakti Kecamatan Palaran Kota Samarinda.

\section{METODE}

Penelitian ini adalah penelitian deskriptif dimana peneliti menguraikan tentang partisipasi peserta keluarga berencana.

HASIL

Tabel 1. Karakteristik Pengertian Umur Responden

\begin{tabular}{lcccc}
\hline Variabel & Frekuensi & $\%$ & Total & $\%$ \\
\hline $20-34$ & 33 & 55 & 60 & 100 \\
$35-49$ & 27 & 45 & &
\end{tabular}


Jurnal Keperawatan Dirgahayu

Volume 2, Nomor 1, Maret 2020

Pada penelitian ini dari 60 responden peserta KB umur 20-34 sebanyak 33 orang $(55 \%)$

Tabel 2 Karakteristik Pendidikan Responden

\begin{tabular}{lllll}
\hline Variabel & Frekuensi & $\%$ & Total & $\%$ \\
& & & & \\
\hline Rendah & 23 & $i 8.33$ & 60 & 100 \\
Tinggi & 37 & 61.67 & &
\end{tabular}

Berdasarkan hasil penelitian dari 60 responden 37 orang mempunyai pendidikan tinggi.(61.67\%)

Tabel 3. Karakteristik Pengetahuan

\begin{tabular}{lllll}
\multicolumn{2}{l}{ Responden } & & & \\
\hline Variabel & Frekuensi & $\%$ & Total & $\%$ \\
& & & & \\
\hline Cukup & 7 & 11.67 & 60 & 100 \\
Baik & 53 & 88.33 & & \\
\hline
\end{tabular}

Berdasarkan hasil penelitian dari 60 responden mempunyai pengetahuan baik 53 orang $(88.33 \%)$.

\section{PEMBAHASAN}

\section{Partisipasi peserta KB berdasarkan umur responden}

Umur ibu 35-49 tahun yang memiliki sikap baik terhadap partisipasi peserta KB 22 orang (81.48\%) dari 27 responden dan yang memiliki pengetahuan cukup terhadap partisipasi keluarga berencana sebanyak $5 \quad(18,52 \%)$ responden.

\section{Tingkat Pendidikan Responden Terhadap Partisipasi keluarga berencana}

Tingkat pendidikan dari 60 responden terhadap partisipasi keluarga berencana juga diperlihatkan Sebanyak 6 (26.09\%) responden dari 23 responden dengan tingkat pendidikan rendah (SDSMP) memilih KB alami dan 17 (73.91\%) responden menjadi peserta $\mathrm{KB}$ efektif. Tingkat pendidikan tinggi (SMA-PT) memilih keluarga berencana efektif sebanyak $21 \quad(56.76 \%)$ dan

\section{EISSN: 2685-3086}

mengikuti keluarga berencana sederhana sebanyak 16 (43.24\%) responden Tingkat pendidikan dari 60 responden terhadap partisipasi keluarga berencana. Sebanyak 6 (26.09\%) responden dari 23 responden dengan tingkat pendidikan rendah (SD-SMP) memilih KB alami 17 $(73.91 \%)$ responden menjadi peserta $\mathrm{KB}$ efektif. Tingkat pendidikan tinggi (SMA-PT) memilih keluarga berencana efektif sebanyak $21 \quad(56.76 \%)$ dan mengikuti keluarga berencana sederhana sebanyak 16 (43.24\%) responden.

Tingkat pendidikan mempengaruhi sikap ibu untuk berpartisipasi menjadi akseptor keluarga berencana.

\section{Pengetahuan Ibu terhadap Partisipasi keluarga berencana}

Sebanyak 60 responden yang mempunyai pengetahuan baik terhadap partisipasi keluarga berencana sebanyak 53 (88.33\%). Pengetahuan yang baik serta sikap yang mendukung merupakan salah satu faktor yang berhubungan terhadap perilaku. Setelah data dianalisis, dari ibu peserta keluarga berencana didapatkan partisipasi berhubungan secara bermakna dengan pengetahuan. Pengetahuan dan partisipasi menjadi pertimbangan dalam menentukan tindakan

\section{KESIMPULAN}

Berdasarkan analisis data dan intepretasinya, maka dapat ditarik kesimpulan partisipasi ibu sebagai peserta keluarga berencana adalah sebagai berikut:

1. Responden umur ibu dalam penelitian berjumlah 60 orang, berumur 20-34 tahun sebanyak 33 orang $(55 \%)$ dan umur $35-49$ tahun sebanyak 27 orang $(45 \%)$

2. Tingkat pendidikan ibu dalam penelitian ini adalah rendah (SDSMP) yaitu sebanyak 23 orang (38.33\%), pendidikan tinggi (SMAPT) sebanyak 37 orang $(61,67 \%)$ 
3. Pengetahuan ibu tentang keluarga berencana dalam penelitian ini adalah baik yaitu sebanyak 53 orang $(88.33 \%)$

4. Hasil analisa menunjukkan bahwa umur ibu mempengaruhi sikap ibu terhadap partisipasi keluarga berencana dengan hasil $p$ value $0.02<$ 0.05 .

5. Hasil analisa menunjukkan bahwa tingkat pendidikan mempengaruhi sikap ibu terhadap partisipasi keluarga berencana dengan hasil $p$ value $0.00<0.05$.

6. Hasil analisa menunjukkan bahwa pengetahuan mempengaruhi sikap ibu terhadap partisipasi keluarga berencana dengan hasil $p$ value $0.00<$ 0.05 .

\section{SARAN}

Berdasarkan kesimpulan hasil penelitian , maka disarankan sebagai berikut :

1. Pada hasil penelitian ini ditemukan bahwa umur, tingkat pendidikan dan pengetahuan terhadap partisipasi keluarga berencana saling berkaitan, karena keterbatasan peneliti sehingga perlu dilakukan penelitian lebih lanjut dengan jumlah sampel yang lebih besar, metode sampling yang lebih akurat dengan mengendalikan factor perancu.

2. Melakukan pendidikan kesehatan kepada calon ibu mengenai pentingnya pendidikan tentang keluarga berencana.

3. Kepada Tenaga Puskesmas /

Kesehatan

Diharapkan kepada seluruh tenaga kesehatan dapat memberikan penyuluhan tentang keluarga berencana, sehingga pasangan usia subur dapat menentukan menjadi peserta keluarga berencana.

4. Bagi Peneliti Selanjutnya
a. Bagi peneliti selanjutnya diharapkan dapat melakukan penelitian lebih baik dari yang

sudah ada dengan memperhatikan keterbatasan penelitian ini.

b. Kaji mengenai kondisi biologis,psikologis, keadaan social budaya klien dan mengikut sertakan anggota keluarga saat penyuluhan

\section{DAFTAR PUSTAKA}

Arikunto S. 2010. "Prosedur Penelitian Suatu Pendekatan Praktik. Jakarta : Rineka Cipta.

Arif, R, 2013. Faktor-faktor yang Mempengaruhi Partisipasi Pasangan Usia Subur dalam Program KB di Kecamatan Kauman Kabupaten Ponorogo

Ahmad Risani, 2017, Analisis FaktorFaktor Yang Berpengaruh Terhadap Keikutsetaan Suami Sebagai Akseptor KB Metode Operasi Pria (MOP) diDesa Nataran Kecamatan Antar Kabupaten lampung Selatan

Bungin, Burhan. 2011. Metodologi Penelitian Kuantitatif. Jakarta : Kencana.Gerson

Elsa Setiawati. S (2017). Persepsi Masyarakat Terhadap Program Kampung KB Di

Kelurahan Pantoloan Boya Kecamatan Tawaeli Penerbit : EJournal Geo-Tadulako UNTAD

Hartanto, Hanafi. 2013. Keluarga Berencana dan Kontrasepsi. Jakarta : Pustaka Sinar Harapan.

Kusumaningrum, 2009. Faktor-faktor yang Mempengaruhi Pemilihan Jenis Kontrasepsi yang Digunakan pada Pasangan Usia subur. Semarang: Artikel Undip. 
Meilani, Niken, dkk. 2010. Pelayanan Keluarga Berencana (dilengkapi dengan penuntun belajar), cetakan I. Yogyakarta: Fitramaya.

Mardiyono, Kampung KB sebagai Upaya Pemberdayaan Masyarakat/Keluarga di Jawa Timur, Jurnal Cakrawala Vol.11 No.2 Desember 2017

Notoatmodjo S. 2010. "Metodologi Penelitian Kesehatan". Jakarta : Rineka Cipta.

------------. $2012 . \quad$ "Promosi Kesehatan dan Perilaku”. Jakarta : Rineka Cipta.

Nursalam. 2008. "Konsep dan Penerapan Metodologi Penelitian Ilmu Keperawatan, . Jakarta : Salemba Medika
Wawan, A dan Dewi, M. 2010. Teori dan Pengukuran Pengetahuan, Sikap dan Perilaku Manusia. Yogyakarta : Nuha Medika

Sudarti, Ken, Prasetyaningtyas, Puji. 2011. Peningkatan Minat Dan Keputusan Berpartisipasi Akseptor $K B$. journal.unnes.ac.id

Taufiqurrahman M. A. 2008. "Pengantar Metologi Penelitian untuk Ilmu Kesehatan". Surakarta: LPP UNS

Zahrah, Partisipasi dalam Program Keluarga berencana (KB) di Kecamatan Pakal Surabaya, Kebijakan dan Manajemen Pubik, Volume 3,Nomor 2,Mei-Agustus 2015 ISSN 2303 - 341X 